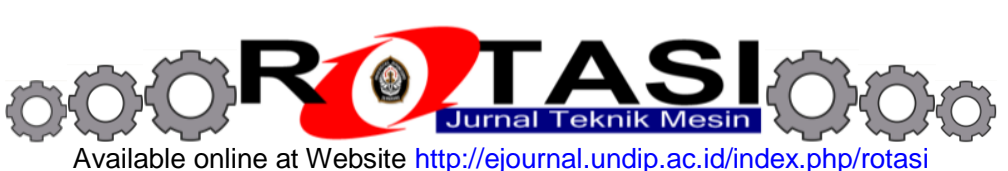

\title{
ANALISIS PENGARUH KANDUNGAN SIC, TEMPERATUR CAIRAN, KECEPATAN PUTAR DAN DURASI WAKTU PENGADUKAN PADA KEKUATAN TARIK KOMPOSIT AL-SIC
}

\author{
*Sadi, Viktor Malau, M. Waziz Wildan, Suyitno \\ Jurusan Teknik Mesin dan Industri, Universitas Gadjah Mada \\ Jl. Grafika no. 2, 5528 Yogyakarta \\ *E-mail: sadi.sadi1971@yahoo.co.id
}

\begin{abstract}
ABSTRAK
Tujuan penelitian ini adalah untuk menganalisis pengaruh kandungan SiC, temperatur cairan, kecepatan putar dan durasi waktu pengadukan pada kekuatan tarik komposit Al-SiC menggunakan metode Taguchi. Material komposit yang digunakan adalah aluminium paduan Al-Si sebagai matrik dan partikel SiC (silicon carbide) ukuran -400 mesh sebagai penguat. Spesimen komposit Al-SiC dibuat menggunakan proses stir casting. Kekuatan tarik spesimen komposit Al-SiC diuji menggunakan mesin uji tarik servopulser. Kandungan $\mathrm{SiC}$, temperatur cairan, kecepatan putar dan durasi waktu pengadukan, masing-masing menggunakan 4 variasi. Hasil eksperimen menunjukkan bahwa menaikkan kecepatan putar pengadukan sampai $300 \mathrm{rpm}$ dan durasi waktu pengadukan sampai 30 menit mampu menaikkan kekuatan tarik komposit $\mathrm{Al}-\mathrm{SiC}$, tetapi menaikkan kandungan $\mathrm{SiC}$ di atas 5 $\%$ berat dan temperatur cairan di atas $680^{\circ} \mathrm{C}$ dapat menurunkan kekuatan tariknya. Kandungan SiC pengaruhnya paling besar pada kekuatan tarik komposit Al-SiC dengan kontribusi 68,86\%. Sruktur mikro coran komposit Al-SiC diamati menggunakan scanning electron microscope (SEM).
\end{abstract}

Kata kunci: Komposit Al-SiC, kekuatan tarik, stir casting, eksperimen, metode Taguchi.

\section{PENDAHULUAN}

Metal matrix composites (MMC) adalah material teknik yang dibentuk menggunakan dua material atau lebih untuk memperoleh material baru yang mempunyai sifat fisis dan mekanis yang lebih baik dibanding material pembentuknya. Matrik yang digunakan untuk membuat MMC biasanya menggunakan logam lunak dan ringan yaitu aluminium, magnesium, dll., sedangkan penguat MMC biasanya menggunakan partikel $\mathrm{SiC}_{2} \mathrm{Al}_{2} \mathrm{O}_{3}$, dll. $\mathrm{Keunggulan}$ MMC dibanding komposit polimer adalah kekerasannya lebih tinggi, tahan aus dan tahan pada temperatur tinggi. Aplikasi MMC pada industri otomotif adalah digunakan untuk cylinder liners mesin, intake valve, exhaust valve, piston, dan lain-lain [1,2]. MMC dapat dibuat menggunakan proses stir casting. Proses stir casting yaitu proses pencairan dan pengadukan (stiring) material di dalam furnace, dilanjutkan proses penuangan ke dalam cetakan logam dengan memanfaatkan gaya gravitasi. Proses ini lebih murah dibanding prosess pembuatan MMC lainnya dan dapat digunakan untuk membuat komponen yang bentuknya rumit $[1,3]$.

Hashim [4], Bhusan, dkk. [5] dan Meena, dkk. [6] meneliti komposit Al-SiC dibuat dengan proses stir casting. Hasil penelitian mereka menyatakan bahwa menaikkan kandungan partikel $\mathrm{SiC}$ pada matrik aluminium dapat menaikkan kekuatan tarik komposit Al-SiC. Kekuatan tarik komposit naik 12,74 \% dengan dinaikkannya kandungan partikel SiC dari 5 sampai $10 \%$ berat. Vanarotti, dkk. [7], menaikkan kandungan partikel SiC dari 5 sampai $10 \%$ berat pada matrik aluminium, kekuatan tarik komposit naik 0,53\%. Tofigh, dkk. [8], menaikkan kandungan partikel SiC pada matrik aluminium dari 1 sampai 3,5\% volume, kekuatan tarik komposit dapat naik tetapi menaikkan kandungan partikel $\mathrm{SiC}$ pada matrik aluminum di atas 3,5\% volume dapat menurunkan kekuatan tariknya.

Permasalahan yang muncul pada pembuatan MMC Al-SiC menggunakan proses stir casting yaitu terjadi pengelompokan partikel SiC pada matrik. Pengelompokan partikel SiC mengurangi kuatnya ikatan antara matrik aluminium dengan partikel SiC. Pengelompokan partikel SiC menjadikan material matrik diantara partikel SiC secara individu ikatannya kurang bagus. Selain pengelompokan partikel SiC pada matrik, permasalahan yang muncul adalah terjadinya porositas [4, 5]. Menurut Aqida [9], porositas terbentuk akibat adanya gelembung udara yang terjebak di dalam cairan komposit Al-SiC pada saat pengadukan. Porositas dapat menurunkan sifat-sifat mekanis komposit Al-SiC. Tujuan penelitian ini adalah untuk menganalisis pengaruh kandungan SiC, temperatur cairan, kecepatan putar dan durasi waktu pengadukan pada proses stir casting komposit Al-SiC terhadap kekuatan tarik menggunakan metode Taguchi.

\section{PROSEDUR EKSPERIMEN}

\subsection{Material}

Pada penelitian ini, aluminium paduan Al-Si digunakan sebagai material matrik komposit dan partikel SiC dengan ukuran butiran -400 mesh $(32 \mu \mathrm{m})$ digunakan sebagai material penguat (reinforcement). Komposisi kimia aluminium paduan Al-Si diuji menggunakan spectrometer dan komposisi kimia partikel SiC diuji menggunakan Energy 
dispersive spectroscope (EDS). Partikel SiC dipasok oleh Sigma Aldrich, Co. USA, dan aluminium paduan Al-Si dipasok oleh Pinjaya Logam, Co., Indonesia.

\subsection{Proses Stir Casting Komposit Al-SiC.}

Aluminium paduan Al-Si dicairkan di dalam graphite crucibles pada resistance furnace sampai di atas titik cairnya yaitu di atas temperatur $680{ }^{\circ} \mathrm{C}$. Tujuannya supaya aluminium paduan Al-Si sudah mencair sempurna sebelum dicampur partikel SiC. Aluminium paduan Al-Si dipanaskan mula pada temperatur $500{ }^{\circ} \mathrm{C}$ selama \pm 3 jam sebelum mencair. Pada saat yang sama partikel SiC juga dipanaskan mula pada temperatur $500{ }^{\circ} \mathrm{C}$ selama \pm 2 jam sebelum dicampur pada cairan aluminium paduan Al-Si supaya tidak terjadi oksidasi. Aluminium paduan Al-Si yang telah mencair sempurna kemudian ditambahkan partikel $\mathrm{SiC}$ secara pelan-pelan dan terus-menerus ke dalam cairan aluminium dan diaduk secara manual, sambil temperaturnya diturunkan mencapai $\pm 580{ }^{\circ} \mathrm{C}$ supaya cairan menjadi slurry dan dijaga dalam kondisi tersebut. Pada kondisi slurry, cairan diaduk dengan motor pada kecepatan $600 \mathrm{rpm}$ selama 20 menit dan dibantu secara manual karena pencampurannya sangat sulit. Setelah partikel SiC mencampur dengan baik pada cairan aluminium, kemudian temperaturnya dinaikkan kembali sampai dalam kondisi cair sempurna sesuai parameter faktor yang telah ditentukan pada desain eksperimen Taguchi seperti pada Tabel 1. Faktor yang digunakan eksperimen yaitu kandungan $\operatorname{SiC}\left(0,5,10,15 \%\right.$ berat), temperatur cairan $\left(680,700,720\right.$ dan $\left.740{ }^{\circ} \mathrm{C}\right)$, kecepatan pengadukan $(100,200,300$ dan $400 \mathrm{rpm})$ dan durasi waktu pengadukan (10, 20, 30 dan 40 menit). Cairan komposit Al-SiC selanjutnya dituang ke dalam cetakan baja yang sebelumnya dipanaskan mula pada temperatur $200{ }^{\circ} \mathrm{C}$ selama \pm 2 jam.

\subsection{Uji Kekuatan Tarik Komposit Al-SiC}

Pengujian kekuatan tarik (tensile strength) komposit Al-SiC dilakukan menggunakan mesin uji tarik jenis servopulser, merek shimadzu dengan kapasitas 30 ton untuk beban statik dan 20 ton untuk beban dinamis. Pengujian kekuatan tarik dilakukan untuk mengetahui seberapa besar beban tarik maksimum yang mampu diterima oleh material. Spesimen uji kekuatan tarik pada penelitian ini menggunakan standar JIS Z2201 no. 7 dengan ukuran seperti pada Gambar 1 [10].

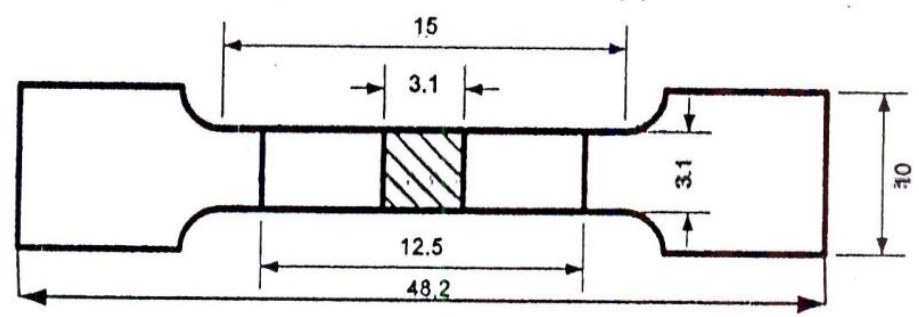

Gambar 1. Dimensi benda uji tarik standar JIS Z2201.

\subsection{Pengamatan Struktur Mikro Komposit Al-SiC}

Pada penelitian ini, spesimen komposit Al-SiC diamati struktur mikronya untuk mengetahui distribusi partikel $\mathrm{SiC}$ pada matrik aluminium. Sebelum diamati struktur mikronya, spesimen komposit Al-SiC dipoles permukaannya sampai halus. Spesimen komposit Al-SiC dipoles permukaannya menggunakan kertas ampelas ukuran 400, 600, 800, 1000, 1200 dan 1500, dilanjutkan dengan kain halus dan autosol. Spesimen komposit Al-SiC yang permukaannya telah dipoles kemudian dietsa dengan cara mencelupkan ke dalam alkohol 95\%. Setelah dietsa, spesimen komposit Al-SiC diamati struktur mikronya menggunakan scaning electron microscope (SEM).

\subsection{Desain Eskperimen Taguchi}

Desain eksperimen pada penelitian ini menggunakan desain eksperimen Taguchi. Faktor dan variasi yang digunakan untuk eksperimen ditunjukkan pada Tabel 1.

Tabel 1. Faktor eksperimen dan variasi parameternya

\begin{tabular}{lcccc}
\hline \multirow{2}{*}{ Faktor eksperimen } & \multicolumn{4}{c}{ Variasi dan parameter faktor } \\
\cline { 2 - 5 } & 1 & 2 & 3 & 4 \\
\hline Kandungan $\mathrm{SiC}(\%$ berat $)$ & 0 & 5 & 10 & 15 \\
\hline Temperatur cairan $\left({ }^{\circ} \mathrm{C}\right)$ & 680 & 700 & 720 & 740 \\
\hline Kecepatan putar $(\mathrm{rpm})$ & 100 & 200 & 300 & 400 \\
\hline Durasi waktu pengadukan (menit) & 10 & 20 & 30 & 40 \\
\hline
\end{tabular}

Faktor eksperimen yang digunakan sebanyak 4 dengan masing-masing 4 variasi, maka derajat bebas total eksperimen adalah 12. Berdasarkan jumlah faktor eksperimen, jumlah variasi parameter faktor eksperimen dan jumlah 
derajat bebas maka standar desain eksperimen menurut metode Taguchi adalah $L_{16}$ orthogonal array, artinya jumlah eksperimen dengan perlakuan berbeda harus dilakukan minimal 16 kali. Tujuan penelitian ini adalah untuk memperoleh kekuatan tarik maksimum. Berdasarkan metode Taguchi nilai signal to noise ratios ( $\mathrm{S} / \mathrm{N}$ ratio) diperoleh menggunakan karakteristik respon larger is better. Untuk memperoleh $S / N$ ratio-larger is better, data hasil uji kekuatan tarik pada masing-masing eksperimen dikonversi menggunakan Persamaan 1 [11].

$$
S / N \text { ratio }=-10 \log _{10}\left[\frac{1}{n} \sum_{i=1}^{n} \frac{1}{y_{i}^{2}}\right]
$$

dimana $S / N$ ratio = signal to noise ratio, $\mathrm{dB}($ decible $)$

$\mathrm{n}=$ jumlah spesimen tiap percobaan

$\mathrm{y}_{\mathrm{i}}=$ kekuatan tarik spesimen ke-i

Eksperimen untuk membuat spesimen uji kekuatan tarik dilakukan sebanyak 16 kali, dengan perlakuan berbeda. Setiap perlakuan dibuat spesimennya sebanyak 5 buah, selanjutnya diuji kekuatan tariknya pada mesin uji tarik dan hasilnya dirata-rata. Total spesimen uji kekuatan tarik untuk 16 eksperimen dengan perlakuan berbeda adalah 80 buah.

\section{HASIL EKSPERIMEN DAN PEMBAHASAN}

\subsection{Hasil Uji Komposisi Kimia aluminium paduan Al-Si dan partikel SiC}

Hasil uji komposisi kimia aluminium paduan Al-Si menggunakan spectrometer dalam persen massa (mass \%) sebagai berikut: 10,516 Si, 1,715 Cu, 0,78 Fe, 0,83 Zn, 0,239 Mg, 0,15 Mn dan balance Al. Hasil uji komposisi kimia partikel SiC menggunakan EDS ditunjukkan pada Tabel 2.

Tabel 2. Komposisi kimia partikel SiC hasil uji EDS

\begin{tabular}{|c|c|c|c|c|c|}
\hline ZAF Met & tandar & s Ouantit & Analysi & ting $\mathrm{Coe}$ & $\mathrm{nt}: 0.343$ \\
\hline Element & $(\mathrm{keV})$ & Mass \% & Error \% & Atom $\%$ & $\mathrm{~K}$ \\
\hline C $\mathrm{K}^{*}$ & 0.277 & 21.87 & 4.45 & 39.56 & 1.2954 \\
\hline $\mathrm{Si} \quad \mathrm{K}$ & 1.739 & 78.13 & 0.52 & 60.44 & 98.7046 \\
\hline Total & & 100.00 & & 100.00 & \\
\hline
\end{tabular}

3.2. Hasil Uji Kekuatan Tarik Komposit Al-SiC

Hasil uji kekuatan tarik dan S/N ratio tiap eksperimen ditunjukkan pada Tabel 3.

Tabel 3. Kondisi eksperimen dan hasil uji kekuatan tarik.

\begin{tabular}{|c|c|c|c|c|c|c|}
\hline \multirow[b]{2}{*}{ Eksp. } & \multicolumn{4}{|c|}{ Faktor eksperimen dan parameternya } & \multirow[b]{2}{*}{$\begin{array}{c}\text { Kekuatan } \\
\text { tarik } \\
(\mathrm{MPa})\end{array}$} & \multirow[b]{2}{*}{$\begin{array}{l}S / N \text { ratios- } \\
\text { larger is better } \\
(\mathrm{dB})\end{array}$} \\
\hline & $\begin{array}{c}\text { Kandungan } \mathrm{SiC} \\
\text { (\% berat })\end{array}$ & $\begin{array}{c}\text { Temperatur } \\
\text { cairan } \\
\left({ }^{\circ} \mathrm{C}\right)\end{array}$ & $\begin{array}{l}\text { Kecepatan } \\
\text { putar (rpm) }\end{array}$ & $\begin{array}{c}\text { Durasi waktu } \\
\text { pengadukan (menit) }\end{array}$ & & \\
\hline 1 & 0 & 680 & 100 & 10 & 191,124 & 45,366 \\
\hline 2 & 0 & 700 & 200 & 20 & 176,528 & 43,837 \\
\hline 3 & 0 & 720 & 300 & 30 & 187,699 & 44,777 \\
\hline 4 & 0 & 740 & 400 & 40 & 110,679 & 40,152 \\
\hline 5 & 5 & 680 & 200 & 30 & 130,747 & 41,368 \\
\hline 6 & 5 & 700 & 100 & 40 & 104,969 & 39,599 \\
\hline 7 & 5 & 720 & 400 & 10 & 101,211 & 40,057 \\
\hline 8 & 5 & 740 & 300 & 20 & 119,136 & 40,745 \\
\hline 9 & 10 & 680 & 300 & 40 & 104,346 & 40,246 \\
\hline 10 & 10 & 700 & 400 & 30 & 94,694 & 39,237 \\
\hline 11 & 10 & 720 & 100 & 20 & 81,304 & 37,511 \\
\hline 12 & 10 & 740 & 200 & 10 & 80,407 & 37,850 \\
\hline 13 & 15 & 680 & 400 & 20 & 98,957 & 39,825 \\
\hline 14 & 15 & 700 & 300 & 10 & 79,461 & 37,817 \\
\hline
\end{tabular}




\begin{tabular}{lllllll}
\hline 15 & 15 & 720 & 200 & 40 & 70,105 & 36,396 \\
\hline 16 & 15 & 740 & 100 & 30 & 98,874 & 39,874 \\
\hline
\end{tabular}

Data respon hasil uji kekuatan tarik diolah untuk membuat tabel respon kekuatan tarik rata-rata dari berbagai perlakuan dan tabel S/N ratio. Pengolahan data menggunakan bantuan software MINITAB 16 dan Excel. Hasil pengolahan data respon eksperimen ditunjukkan pada Tabel 4 dan Tabel 5.

Tabel 4. Respon kekuatan tarik rata-rata komposit Al-SiC

\begin{tabular}{lcccccc}
\hline \multirow{2}{*}{ Faktor eksperimen } & \multicolumn{2}{c}{ Variasi parameter faktor dan } & kekuatan tarik rata-rata (MPa) & \multirow{2}{*}{ Selisih } & \multirow{2}{*}{ Peringkat } \\
\cline { 2 - 5 } & 1 & 2 & 3 & 4 & & \\
\hline Kandungan $\mathrm{SiC}(\%$ berat$)$ & 166,51 & 114,02 & 90,19 & 86,85 & 79,66 & 1 \\
\hline Temperatur cairan $\left({ }^{\circ} \mathrm{C}\right)$ & 131,29 & 113,91 & 110,08 & 102,27 & 29,02 & 3 \\
\hline Kecepatan putar $(\mathrm{rpm})$ & 119,07 & 114,45 & 122,66 & 101,38 & 21,28 & 4 \\
\hline Durasi waktu pengadukan (menit) & 113,05 & 118,98 & 128,00 & 97,52 & 30,48 & 2 \\
\hline
\end{tabular}

Tabel 5. Respon $S / N$ ratios-larger is better komposit Al-SiC

\begin{tabular}{|c|c|c|c|c|c|c|}
\hline \multirow{2}{*}{ Faktor eksperimen } & \multicolumn{2}{|c|}{ Variasi parameter faktor dan } & \multicolumn{2}{|c|}{ S/N ratios-larger is better $(\mathrm{dB})$} & \multirow{2}{*}{ Selisih } & \multirow{2}{*}{ Peringkat } \\
\hline & 1 & 2 & 3 & 4 & & \\
\hline Kandungan $\mathrm{SiC}(\%$ berat $)$ & 43,53 & 40,44 & 38,71 & 38,48 & 5,05 & 1 \\
\hline Temperatur cairan $\left({ }^{\circ} \mathrm{C}\right)$ & 41,70 & 40,12 & 39,69 & 39,66 & 2,05 & 3 \\
\hline Kecepatan putar (rpm) & 40,59 & 39,86 & 40,90 & 39,82 & 1,08 & 4 \\
\hline Durasi waktu pengadukan (menit) & 40,27 & 40,48 & 41,31 & 39,10 & 2,22 & 2 \\
\hline
\end{tabular}

Berdasarkan Tabel 4 dan Tabel 5, urutan peringkat (ranking) faktor eksperimen yang mempengaruhi kekuatan tarik komposit Al-SiC adalah kandungan SiC, durasi waktu pengadukan, temperatur cairan dan kecepatan putar.

\subsection{Pengaruh Faktor Eksperimen pada Kekuatan Tarik Komposit Al-SiC.}

Pengaruh faktor eksperimen pada kekuatan tarik dan S/N ratio komposit Al-SiC ditunjukkan pada Gambar 2 dan Gambar 3.

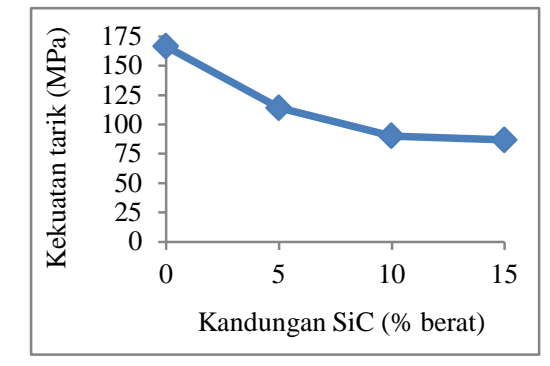

(a)

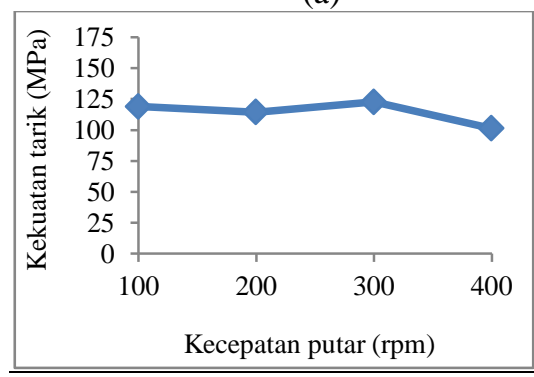

(c)

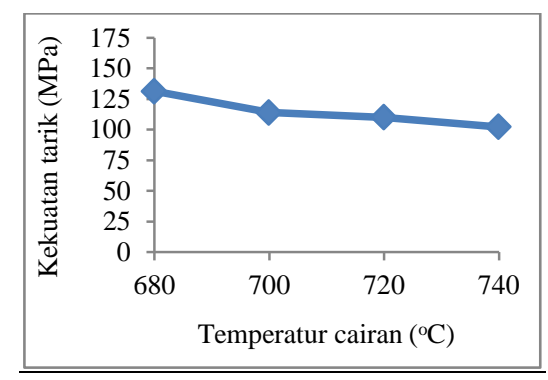

(b)

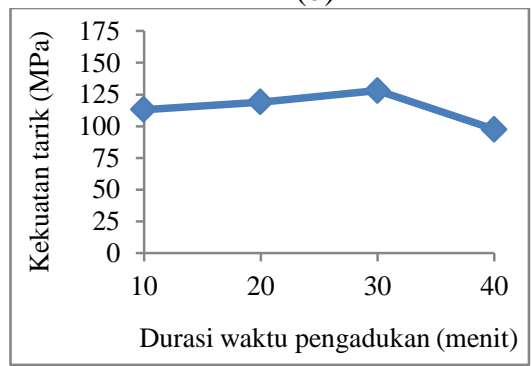

(d)

Gambar 2. Pengaruh faktor eksperimen pada kekuatan tarik rata-rata komposit Al-SiC; (a) Pengaruh kandungan SiC pada kekuatan tarik, (b) Pengaruh temperatur cairan pada kekuatan tarik, (c) Pengaruh kecepatan putar pada kekuatan tarik, (d) Pengaruh durasi waktu pengadukan pada kekuatan tarik

Berdasarkan Gambar 2 (a), ditunjukkan bahwa pengaruh menaikkan kandungan SiC dari 5 sampai $15 \%$ berat pada spesimen komposit $\mathrm{Al}-\mathrm{SiC}$ yang dibuat dengan proses stir casting menjadikan kekuatan tarik rata-rata komposit menurun sebesar 23,83 \%. Kekuatan tarik rata-rata komposit Al-SiC menurun dari 114,02 MPa menjadi 86,85 MPa. Hasil uji kekuatan tarik ini sesuai dengan penelitian yang dilakukan oleh Sahin, dkk. [12]. Hasil penelitiannya menyatakan bahwa menaikkan kandungan SiC dari 5 sampai $15 \%$ berat pada proses stir casting menjadikan kekuatan 
tarik komposit Al-SiC menurun. Kekuatan tarik komposit Al-SiC menurun, karena menaikkan kandungan SiC dari 5 sampai $15 \%$ berat dapat menaikkan porositasnya. Pada Gambar 3 (a), S/N ratio tertinggi komposit Al-SiC terjadi pada variasi ke dua sebesar 40,44 dB dengan kandungan $\mathrm{SiC} 5 \%$ berat, maka kandungan $\mathrm{SiC}$ optimum adalah $5 \%$ berat.

Pengaruh temperatur cairan pada kekuatan tarik rata-rata komposit Al-SiC ditunjukkan pada Gambar 2 (b). Berdasarkan Gambar 2 (b) ditunjukkan bahwa menaikkan temperatur cairan dari 680 sampai $740{ }^{\circ} \mathrm{C}$, kekuatan tarik rata-rata komposit $\mathrm{Al}-\mathrm{SiC}$ menurun sebesar 22,1\%. Kekuatan tarik rata-rata komposit menurun dari 131,29 menjadi 102,27 MPa. Berdasarkan Gambar 3 (b), pengaruh temperatur cairan pada $S / N$ ratio tertinggi terjadi pada variasi ke satu sebesar $41,70 \mathrm{~dB}$, maka temperatur cairan optimum adalah $680^{\circ} \mathrm{C}$.

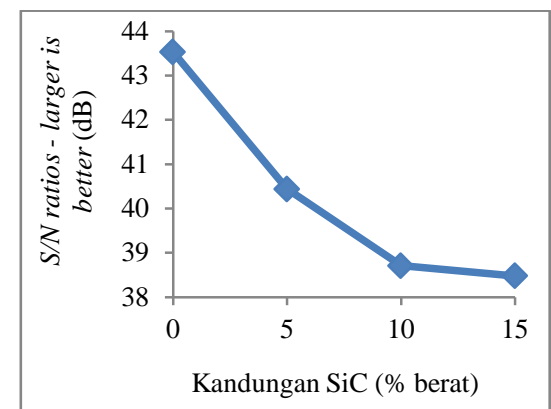

(a)

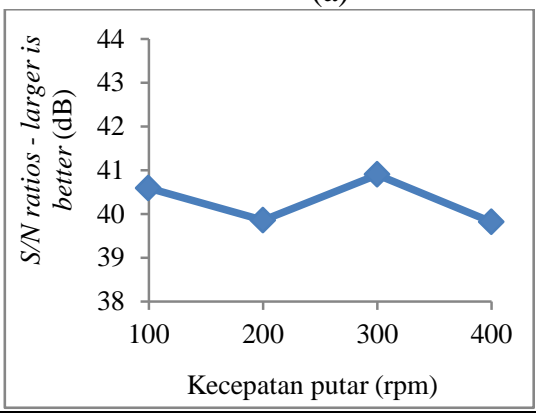

(c)

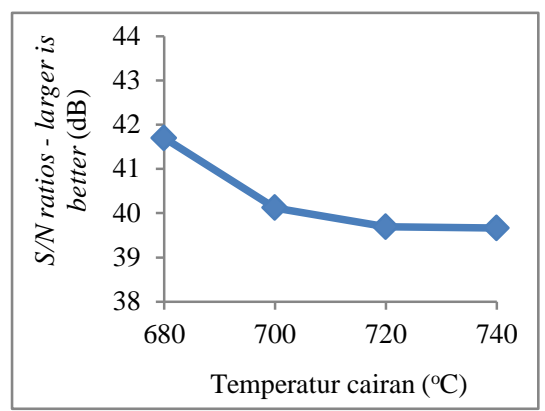

(b)

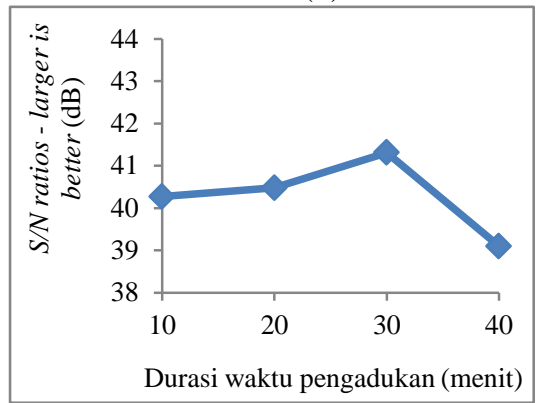

(d)

Gambar 3. Pengaruh faktor eksperimen pada $S / N$ ratios - larger is better; (a) Pengaruh kandungan $\mathrm{SiC}$ pada $S / N$ ratios-larger is better, (b) Pengaruh temperatur cairan pada $S / N$ ratios-larger is better, (c) Pengaruh kecepatan putar pada S/N ratios-larger is better, (d) Pengaruh durasi waktu pengadukan pada S/N ratios-larger is better.

Pengaruh kecepatan putar pengadukan pada kekuatan tarik komposit Al-SiC juga ditunjukkan pada Gambar 2 (c). Berdasarkan Gambar 2 (c), kekuatan tarik rata-rata komposit Al-SiC menurun dari 119,07 menjadi 114,45 MPa jika kecepatan putar dinaikkan dari 100 menjadi $200 \mathrm{rpm}$, tetapi kekuatan tarik rata-ratanya naik kembali menjadi 122,66 MPa ketika kecepatan putar pengadukan $300 \mathrm{rpm}$. Pada kecepatan putar pengadukan 400 rpm kekuatan tariknya menurun kembali menjadi 101,38 MPa. Pada penelitian ini, ketika kecepatan putar pengadukan dinaikkan dari 100 menjadi 300 rpm, kekuatan tarik rata-rata komposit Al-SiC naik sebesar 3,02 \%, yaitu naik dari 119,07 MPa menjadi 122,66 MPa. Berdasarkan Gambar 3 (c), ditunjukkan bahwa sinyal tertinggi terjadi pada variasi ke tiga dengan $S / N$ ratio sebesar 40,90 dB, maka kecepatan putar optimum adalah $300 \mathrm{rpm}$.

Pengaruh durasi waktu pengadukan pada kekuatan tarik rata-rata komposit Al-SiC juga ditunjukkan pada Gambar 2 (d). Berdasarkan Gambar 2 (d), menambah durasi waktu pengadukan dari 10 menjadi 30 menit dapat menaikkan kekuatan tarik komposit Al-SiC sebesar 13,22 \% yaitu dari 113,05 MPa menjadi $128 \mathrm{MPa}$, tetapi menambah durasi waktu pengadukan di atas 30 menit akan menurunkan kekuatan tarik rata-ratanya. Kekuatan tarik rata-rata komposit Al-SiC menurun menjadi 97,52 MPa, ketika durasi waktu pengadukan ditambah menjadi 40 menit. Berdasarkan Gambar 3 (d), S/N ratio tertinggi terjadi pada variasi ke tiga yaitu durasi waktu pengadukan 30 menit dengan $S / N$ ratio sebesar 41,31 dB, maka durasi waktu pengadukan optimum adalah 30 menit.

Kontribusi masing-masing faktor eksperimen pada kekuatan tarik komposit Al-SiC ditunjukkan pada Gambar 4. 


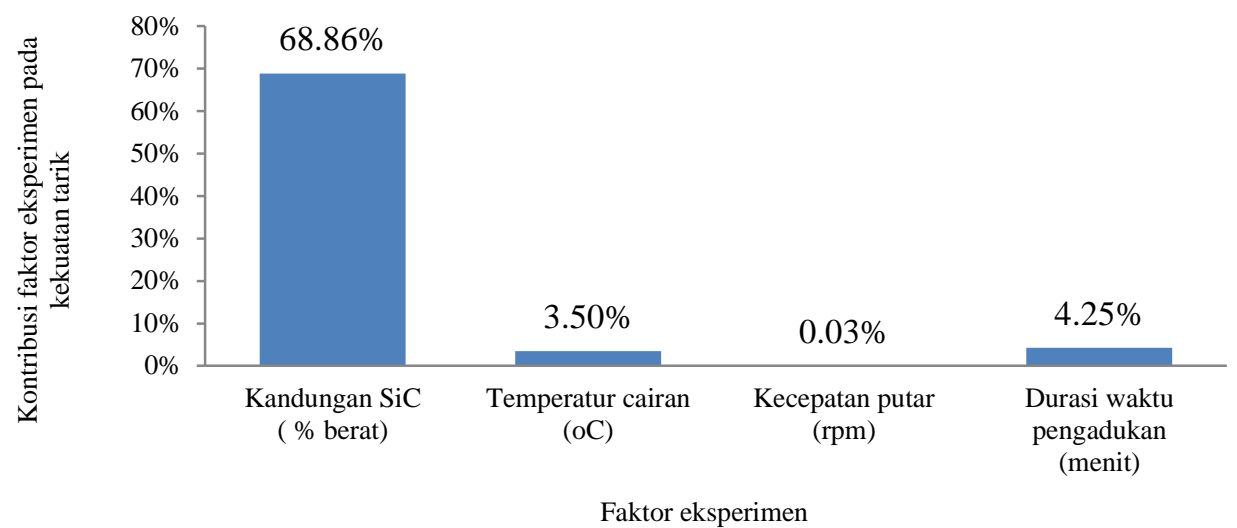

Gambar 4. Kontribusi faktor eksperimen pada kekuatan tarik.

Berdasarkan Gambar 4, faktor eksperimen yang memiliki kontribusi paling besar pada kekuatan tarik komposit Al-SiC adalah kandungan $\mathrm{SiC}$ sebesar $68,86 \%$, dilanjutkan durasi waktu pengadukan 4,25 \%, temperatur cairan 3,5\% dan kecepatan putar $0,03 \%$. Berdasarkan hasil pembahasan pengaruh faktor eksperimen pada kekuatan tarik komposit $\mathrm{Al}-\mathrm{SiC}$ di atas, maka parameter faktor optimum pada proses stir casting terhadap kekuatan tarik komposit Al-SiC adalah kandungan SiC $5 \%$ berat, temperatur cairan $680{ }^{\circ} \mathrm{C}$, kecepatan putar $300 \mathrm{rpm}$ dan durasi waktu pengadukan 30 menit.

\subsection{Struktur Mikro Komposit Al-SiC}

Hasil pengamatan struktur mikro distribusi partikel SiC pada matrik komposit Al-SiC menggunakan SEM ditunjukkan pada Gambar 5. Hasil pengamatan distribusi partikel SiC pada spesimen komposit Al-SiC dengan kandungan $\mathrm{SiC}$ yang berbeda yaitu $0,5,10$ dan $15 \%$ berat terlihat jelas pengaruhnya pada struktur mikronya. Menaikkan kandungan $\mathrm{SiC}$ dapat menambah jumlah partikel SiC yang menyebar pada matrik komposit. Semakin besar kandungan $\mathrm{SiC}$ semakin banyak jumlah partikel $\mathrm{SiC}$ yang terlihat pada struktur mikronya.

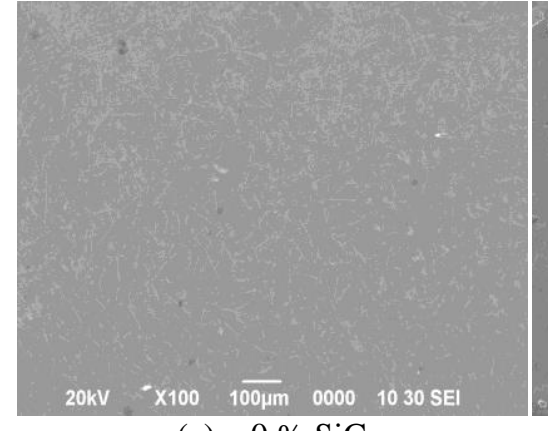

(a) $0 \% \mathrm{SiC}$

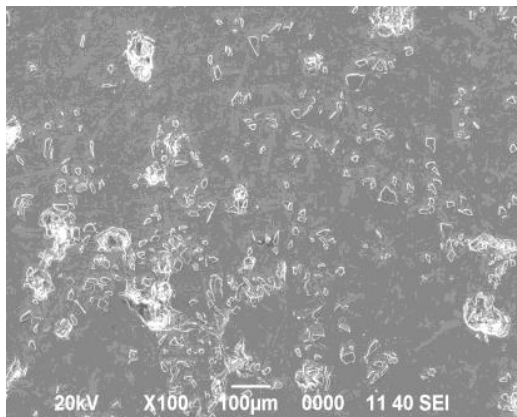

(C) $10 \% \mathrm{SiC}$

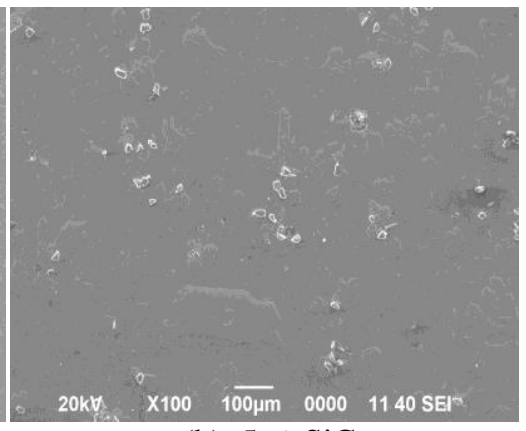

(b) $5 \% \mathrm{SiC}$

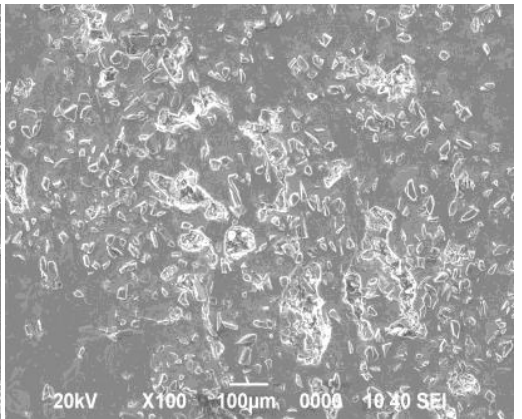

(d) $15 \% \mathrm{SiC}$

Gambar 5. Struktur mikro distribusi partikel SiC pada matrik aluminium

Distribusi partikel SiC pada matrik komposit terlihat kurang merata dan mengelompok. Pengelompokan ini menjadikan pembasahan matrik aluminium pada partikel SiC tidak sempurna dan menyebabkan porositas berupa rongga halus pada permukaan partikel SiC seperti ditunjukkan pada Gambar 6. Porositas berupa rongga halus ini menjadikan ikatan antara permukaan partikel SiC dengan matrik aluminium menjadi berkurang dan menjadikan kekuatan tarik komposit menurun. 


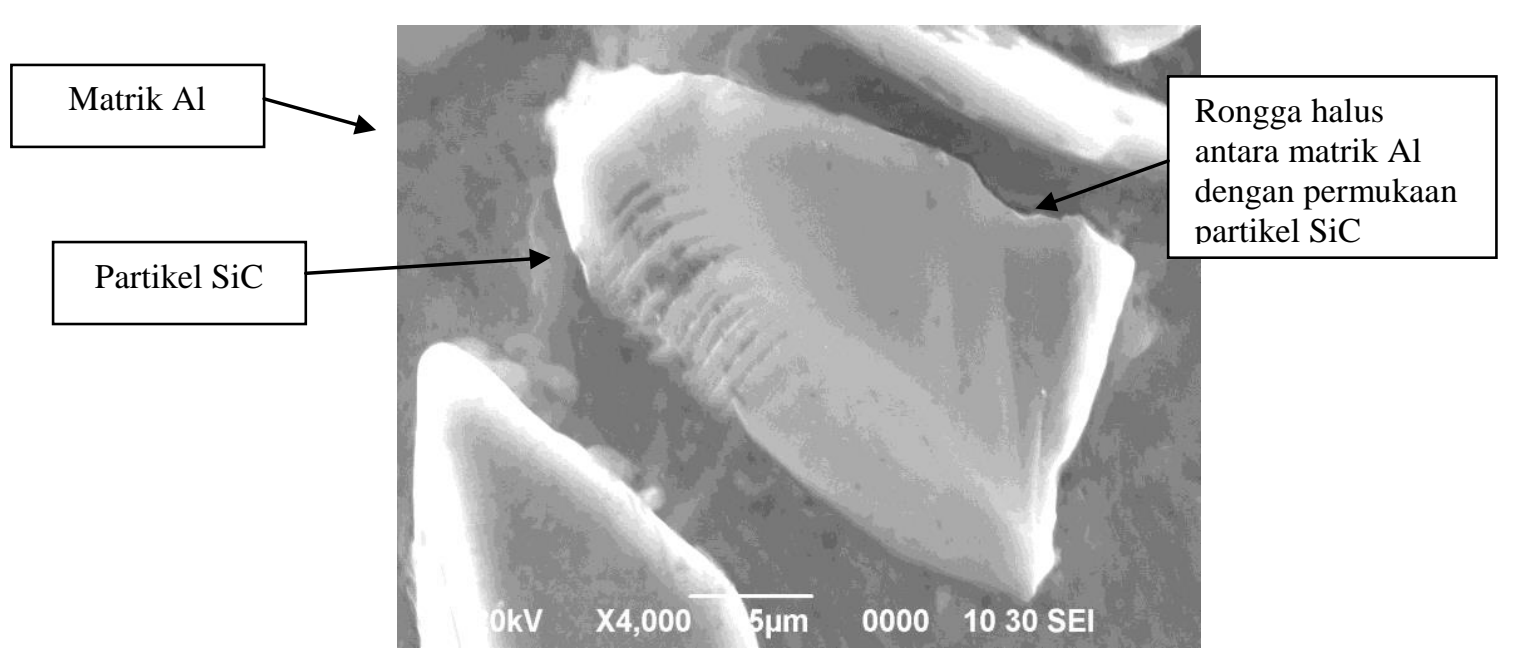

Gambar 6. Hasil pengamatan permukaan partikel SiC menggunakan SEM

\section{KESIMPULAN}

Berdasarkan analisis hasil eksperimen dan pembahasan, maka dapat disimpulkan pengaruh faktor pada proses stir casting terhadap kekuatan tarik komposit Al-SiC sebagai berikut:

a. Menaikkan kecepatan putar pengadukan dari $100 \mathrm{rpm}$ menjadi $300 \mathrm{rpm}$ dan durasi waktu pengadukan dari 10 menit menjadi 30 menit dapat menaikkan kekuatan tarik komposit Al-SiC, tetapi menaikkan kandungan SiC di atas $5 \%$ dan temperatur cairan di atas $680{ }^{\circ} \mathrm{C}$ dapat menurunkan kekuatan tariknya.

b. Kandungan SiC pengaruhnya paling besar pada kekuatan tarik komposit Al-SiC dengan kontribusi $68,86 \%$.

c. Struktur mikro coran komposit Al-SiC yang dibuat dengan proses stir casting hasilnya kurang merata karena partikel SiC punya kecenderungan mengelompok.

d. Parameter faktor optimum pada proses stir casting terhadap kekuatan tarik adalah kandungan $\mathrm{SiC} 5 \%$ berat, temperatur cairan $680{ }^{\circ} \mathrm{C}$, kecepatan putar pengadukan $300 \mathrm{rpm}$ dan lamanya waktu pengadukan 30 menit.

\section{DAFTAR PUSTAKA}

[1] Kainer, K. U., 2006, "Metal Matrix Composites”, Wiley-VCH Verlag GmbH \& Co. KgaA, Weinheim, Chap. 1.

[2] Surappa, M. K., 2003, “Aluminium matrix composites: Challenges and opportunities”, Sadhana, vol. 28, pp. 319334.

[3] Chawla, N. dan Chawla, K. K., 2006, “Metal Matrix Composites”, Springer, USA, Chap. 4.

[4] Hashim, J., 2001, "The Production of Cast Metal Matrix Composite by A Modified Stir Casting Method", Jurnal Teknologi, Universiti Teknologi Malaysia, vol. 35, pp. 9-20.

[5] Bhushan, R. K. dan Kumar, S., 2011, "Influence of SiC Particles Distribution and Their Weight Percentage on 7075 Al Alloy", Journal of Materials Engineering and Performance, vol. 20, pp. 317-323.

[6] Meena, K. L., Manna, A., Banwait, S. S. dan Jaswanti, 2013, “An Analysis of Mechanical Properties of the Developed Al/SiC-MMC's", American Journal of Mechanical Engineering, vol. 1, pp. 14-19.

[7] Vanarotti, M., Kori, S. A., Sridhar, B. R. dan Padasalgi, S. B., 2012, "Synthesis and Characterization of Aluminium Alloy A356 and Silicon Carbide Metal Matrix Composite", 2nd International Conference on Industrial Technology and Management, IPCIT Singapore, vol. 49, pp. 11-15.

[8] Tofigh, A. A. dan Shabani, M. O., 2013, "Applying Various Training Algorithms, in Data Analysis of Nano Composites", Acta Metallurgica Slovaca, vol. 19, pp. 94-104.

[9] Aqida, S. N., Ghazali, M. I. dan Hashim, J., 2004, "Effects of Porosity on Mechanical Properties of Metal Matrix Composite: An Overview”, Jurnal Teknologi, Universiti Teknologi Malaysia, vol. 40, pp. 17-32.

[10] JIS, 1973, “Japanese International Standards”, Non Ferrous Metal, Standard JIS Z2201 no. 7 Test piece.

[11] Belavendram, N., 1995, “Quality by Design: Taguchi Techniques for Industrial Experimentation”, Prentice Hall, London.

[12] Sahin, I. dan Eker, A. A., 2011, "Analysis of Microstructures and Mechanical Properties of Particle Reinforced AlSi7Mg2 Matrix Composite Materials”, Journal of Materials Engineering and Performance, vol. 20, pp. 10901096. 